\title{
Pola Pertumbuhan dan Faktor Kondisi Ikan Brek (Barbonymus balleroides val. 1842) dari Perairan Pulau Jawa Koleksi Museum Zoologi Bogoriense (MZB)
}

\author{
Riza Maizul1, Siti Mukhlishoh Setyawati², Gema Wahyudewantoro³ \\ ${ }^{1}$ Program Studi Biologi, Fakultas Sains dan Teknologi, UIN Walisongo Semarang \\ ${ }^{2}$ Jurusan Pendidikan Biologi, Fakultas Sains dan Teknologi, UIN Walisongo Semarang \\ 3 Puslit Biologi-LIPI Jl. Raya Jakarta Bogor Km 46 Bogor 16911 \\ Email: ${ }^{1}$ gema_wahyudewantoro@yahoo.com
}

\begin{abstract}
Brek fish (Barbonymus balleroides) is a consumption, fish that is widely used by people around the River. The population has started to decline, but not yet cultivated. Therefore, research has been conducted as a basis for its domestication, including growth patterns and condition factor of Brek Fish. The total length (TL) of each individual was measured using a digital caliper with an accuracy of $0.05 \mathrm{~mm}$, while the body weight was weighed using an analytical scale with an accuracy of $0.0001 \mathrm{~g}$. the data obtained were analyzed by linear regression found in the microsoft excel program. The results showed that the growth pattern of brek fish was allometric negative, the average condition factor value of brek fish (B. balleroides) was 1.026. The author hopes this research can be used as basic biological information to support the conservation of Brek Fish (B. ballerodes).
\end{abstract}

Keywords: Barbonymus balleroides, growth patterns, condition factor

\section{Pendahuluan}

Ikan brek merupakan anggota famili Cyprinidae yang banyak dimanfaatkan sebagai ikan konsumsi. Menurut Yulfiperius (2006), meskipun status ikan ini belum termasuk langka namun perlu dilindungi karena di beberapa tempat populasinya sudah menurun. Sejauh ini, upaya konservasi sudah banyak dimulai tetapi belum berhasil.

Ikan brek mempunyai sebaran yang luas di Jawa dan mempunyai beberapa nama lokal. Di wilayah Jawa Barat, jenis ikan ini lebih dikenal dengan nama lalawak yang dapat ditemukan di Sungai Cimanuk Kabupaten Sumedang (Luvi 2000, Rahardjo \& Sjafei 2004). Di Jawa Tengah dikenal pula dengan nama tawes merah yang diantaranya terdapat di Waduk Gadjah Mungkur (Utomo et al. 2008). Kajian mengenai aspek biologi ikan brek masih terbatas. Beberapa penelitian tentang ikan brek pernah dilakukan, antara lain di Waduk Lahor (Lumbanbatu 1979,
Affandi 1979), Waduk Jatiluhur (Sutardja 1980); Sungai Cimanuk (Rahardjo \& Sjafei 2004, Surawijaya 2004, Defira 2004, Yulfiperius 2006, Fajarwati 2006); dan di kawasan tengah (hilir) Sungai Serayu oleh Susatyo et al. (2011).

Di sungai Serayu ikan ini mulai terancam populasinya dikarenakan beberapa faktor diantaranya ialah karena aktivitas penangkapan yang tinggi serta penggunaan alat tangkap yang merusak, selain itu juga dikarenakan adanya fragmentasi habitat akibat pembangunan waduk Mrica dan adanya degradasi habitat (Haryono 2015).

Sehubungan dengan itu untuk menunjang usaha konservasi dan budidayanya dilakukan penelitian yang bertujuan mengetahui aspek biologi dasar diantaranya pola pertumbuhan dan Faktor kondisi ikan brek (B. balleroides).

\section{Metode}

Penelitian ini dilakukan di Laboratorium Iktiologi, Museum Zoologi Bogor (MZB), 
Cibinong, Bogor, Jawa Barat. Selanjutnya brek diukur dengan mempergunakan digital calliper merk Mituyo dengan ketelitian 0,05mm, sedangkan untuk berat total dipergunakan timbangan digital Mettler toledo ketelitian 0,0001 gram. Sebanyak 24 ekor ikan brek (B. balleroides) hasil kerja lapangan peneliti LIPI di Sungai Serayu, Banjarnegara, Jawa Tengah bulan juli 2017. Sebanyak 41 ekor ikan brek (B. balleroides) koleksi Museum Zoologi Bogoriense (MZB) diantaranya ikan brek yang diperoleh dari Sungai Lusi Grobogan, Jawa Tengah sebanyak 14 ekor (no Reg: 10014), Gajah Mungkur, Bengawan Solo, Surakarta, Jawa Tengah 2 ekor (no Reg: 10013), S. Bengawan Solo, Bojonegoro, Jawa Timur 4 ekor (No reg: 10053), S. Brantas Ploso Tambangan, Jawa Timur 2 ekor (No Reg: 8687), S. Brantas DAM lengkong, Mojokerto, Jawa Timur (No Reg: 10051), S. Surabaya, Cangkir, Jawa Timur (No Reg: 8683), S. Brantas Kodya Kediri, Jawa Timur (No Reg: 6154) dan S. Brantas DAM Lengkong, Mojokerto, Jawa Timur (No Reg: 10054).

Parameter yang diamati dihitung berdasarkan rumus menurut Effendie (2002), yaitu:

Hubungan panjang (L) dan berat (W) dengan rumus:

$$
\mathbf{W}=\mathbf{a L}^{\mathbf{b}}
$$

$W$ adalah bobot (g), L adalah panjang total (mm), $a$ adalah intercept garis regresi, dan $b$ adalah slope regresi. Ikan dikatakan mempunyai pertumbuhan isometrik ketika pertambahan panjang sejalan dengan pertambahan bobot. Koefisien untuk pertumbuhan isometrik adalah tiga, sedangkan nilai yang lebih besar atau lebih kecil dari „3" mengindikasikan pertumbuhan allometrik (Effendie 1997).

Faktor kondisi $(\mathrm{K})$, dihitung dengan rumus sebagai berikut:

$$
K=\frac{W}{a L^{b}}
$$

$K$ adalah faktor kondisi, $W$ adalah bobot tubuh (g), L adalah panjang total (mm), a dan b adalah konstanta.

\section{Hasil dan Pembahasan \\ Pola pertumbuhan Ikan Brek (Barbonymus balleroides Val. 1842)}

Jumlah ikan brek yang diteliti sebanyak 65 ekor, dengan rincian 24 ekor hasil kerja lapangan di Sungai Serayu bulan april 2017, dan 41 ekor ikan brek koleksi Museum Zoologi Bogoriense (MZB), ukuran ikan bervariasi, yaitu dengan kisaran panjang total 44,2 mm-229,3 mm dan bobot tubuh 1,193-115,536 gram.

Hubungan panjang bobot dihitung berdasarkan 65 ekor ikan brek yang terdiri atas 24 ekor dari sungai serayu dan 41 ekor koleksi MZB (Pulau Jawa). Hasil analisis ditemukan persamaan regresi $\mathrm{W}=0,028 \mathrm{~L}^{2,671}, \mathrm{R}^{2}=0,959$ (Gambar 1). Pola pertumbuhan ikan brek disajikan pada Tabel 1.

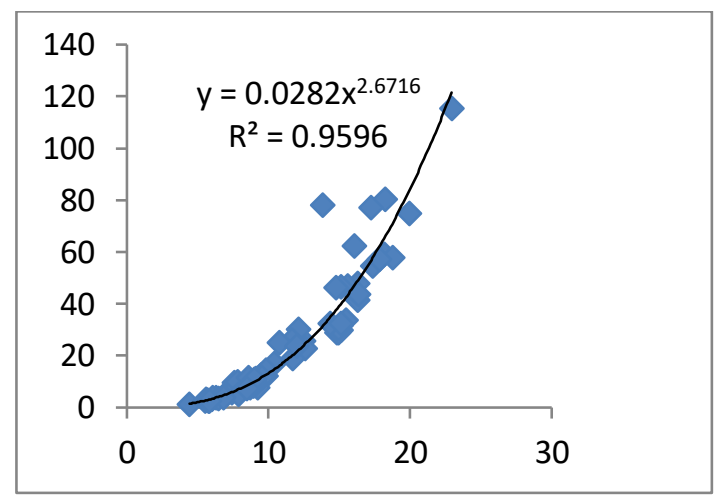

Gambar 1. Hubungan panjang berat ikan brek

Tabel 1. Hubungan panjang berat dan pola pertumbuhan ikan brek

\begin{tabular}{|l|l|l|l|}
\hline $\mathrm{N}$ & Nilai b & $\mathrm{R}^{2}$ & Pola Pertumbuhan \\
\hline 65 & 2,671 & 0,959 & Alometrik Negatif \\
\hline
\end{tabular}

Pada penelitian ini diperoleh nilai koefisien determinasi $\left(\mathrm{r}^{2}\right)$ untuk persamaan regresi hubungan Panjang berat (HPB) sebesar 0,959 Hasil tersebut menunjukkan bahwa terdapat keeratan antara panjang dengan berat sebesar $95,9 \%$. yang mengindikasikan pertambahan panjang akan berpengaruh terhadap bobot tubuh. 
Effendie (1997) menyatakan bahwa hubungan panjang berat menunjukkan pertumbuhan yang bersifat relatif yang berarti dapat dimungkinkan berubah menurut waktu. Apabila terjadi perubahan terhadap lingkungan dan ketersediaan makanan diperkirakan nilai ini juga akan berubah. Meretsky et al., (2000) menambahkan bahwa perubahan bobot ikan dapat dihasilkan dari perubahan pakan dan alokasi energi untuk tumbuh dan reproduksi, yang mengakibatkan bobot ikan berbeda walaupun panjangnya sama.

HPB pada ikan dipengaruhi oleh sejumlah faktor antara lain habitat, makanan, fase pertumbuhan, musim, derajat kepenuhan isi lambung, jenis kelamin, kematangan gonad, dan kondisi umum ikannya. Faktor-faktor tersebut digambarkan dengan besaran nilai $b$ (Sarkar et al. 2013). Besaran nilai $b$ pada penelitian ini sebesar 2,671, Nilai ini menunjukan bahwa Pola pertumbuhan ikan brek allometrik negatif (nilai $\mathrm{b}<3$ ). Hal tersebut menunjukkan bahwa ikan lebih cepat memanjang dibandingkan pertambahan bobotnya. Bila dilihat memang Brek termasuk ikan aktif, jadi energi yang dibutuhkan untuk bergerak (berenang) relatif besar yang diduga mengakibatkan terjadi pola pertumbuhan ikan brek bersifat allometrik negatif.

Hasil ini diperkuat oleh pernyataan Muchlisin et al. (2010) bahwa besar kecilnya nilai $b$ dipengaruhi oleh perilaku ikan, misalnya ikan yang berenang aktif menunjukkan nilai $b$ yang lebih rendah bila dibandingkan dengan ikan yang berenang pasif. Mungkin hal ini terkait dengan alokasi energi yang dikeluarkan untuk pergerakan dan pertumbuhan.

Beberapa penulis melaporkan bahwa pola pertumbuhan ikan brek yang berasal dari berbagai perairan di Jawa mencakup isometrik maupun allometrik. Lumbanbatu (1979) melaporkan dari Waduk Lahor di Jawa Timur baik jantan maupun betina adalah allometrik negatif; Sutardja (1980) melaporkan dari Waduk Jatiluhur di Jawa Barat adalah isometrik; di Sungai Cimanuk jantan allometrik negatif dan betina isometrik (Luvi 2000), Hariyono (2015) melaporkan dari Sungai Serayu di Jawa Tengah Pola pertumbuhan ikan brek pada setiap zona allometrik positif terkecuali ikan jantan di zona tengah dan atas sungai. Hal ini tampak bahwa pola pertumbuhan ikan tergantung pada lokasi dan jenis kelamin. Selain itu, Anene (2005) menyatakan bahwa faktor lingkungan menjadi hal penting untuk dipertimbangkan terkait dengan perbedaan ruang dan waktu terhadap pertumbuhan ikan.

\section{Faktor Kondisi}

Faktor kondisi seringkali digambarkan sebagai kondisi kemontokan atau kegemukan ikan, dimana juga menunjukkan ketersediaan pakan di habitat ikan tersebut. Araneda et al. (2008) berpendapat bahwa informasi tentang faktor kondisi sangat dibutuhkan dalam hal pengelolaan sistem budidaya dikarenakan dapat menunjukkan kondisi spesifik ikan yang dibudidayakan.

Hasil analisa nilai faktor kondisi rata rata B. balleroides yaitu 1,026586. Nilai faktor kondisi yang tinggi mengindikasikan bahwa kondisi lingkungan dan ketersediaan makanan disuatu tempat (dalam hal ini beberapa sungai di Pulau Jawa) menunjukkan adanya kecocokan antara ikan brek dengan lingkungannya.

Menurut Anene (2005), faktor kondisi sangat dipengaruhi oleh kondisi lingkungan baik biotik maupun abiotik dan dapat digunakan sebagai indeks untuk mengetahui status ekosistem perairan dimana ikan hidup. Menurut Haryono (2015), kondisi perairan Sungai Serayu, secara fisik dan kimiawi masih cukup baik untuk mendukung pertumbuhan ikan brek.

\section{Simpulan}

Hasil penelitian menunjukan Pola pertumbuhan ikan brek allometrik negatif dan ratarata nilai faktor kondisi sebesar 1,026586. Faktor kondisi yang diperoleh menunjukkan hasil yang mendukung di dalam pertumbuhan ikan brek baik jantan maupn betina.

\section{Ucapan Terima kasih}

Ucapan terima kasih pada kegiatan KSK Ikan brek (Barbonymus balleroides) tahun 2018 di 
Museum Zoologi Bogoriense, Bidang Zoologi-Pusat Penelitian Biologi-LIPI

\section{Daftar Pustaka}

Anene A. 2005. Condition factor of four cichlid species of a man-made lake in Imo State, Southeastern Nigeria. Turkish Journal of Fisheries and Aquatic Sciences 5: 43-47.

Effendie, M. I. 1997. Biologi perikanan. Bogor: Yayasan Pustaka Nusatama.

Effendi, M. I. 2002. Biologi Perikanan. Bogor: Yayasan Dewi Sri.

Fajarwati, E. N. 2006. Aspek eko-biologi ikan lalawak (Barbodes balleroides) pada berbagai ketinggian tempat di Kabupaten Sumedang, Jawa Barat. Skripsi. Fakultas Perikanan dan Ilmu Kelautan IPB Bogor.

Haryono. 2015. Pengelolaan Ikan Brek (Barbonymus balleroides Val. 1842) Berdasarkan Aspek Ekobiologi Di Kawasan Hulu Sungai Serayu Jawa Tengah. Disertasi: Sekolah Pascasarjana IPB, Bogor.

Lumbanbatu, D. T. F. 1979. Aspek biologi reproduksi beberapa jenis ikan di Waduk Lahor Jawa Timur. Karya Ilmiah. Fakultas Perikanan IPB Bogor.

Luvi, D. M. 2000. Aspek reproduksi dan kebiasaan makan ikan lalawak (Barbodes balleroides) di Sungai Cimanuk Sumedang Jawa Barat. Skripsi. Fakultas Perikanan dan Ilmu Kelautan IPB Bogor.

Rahardjo, M. F., Sjafei, D. S. 2004. Aspek biologi reproduksi dan kebiasaan makan ikan lalawak (Barbodes balleroides) di Sungai Cimanuk. Biosfera. 2 (2): 37-43.

Surawijaya, A. A. 2004. Studi morfologi beberapa jenis ikan lalawak (Barbodes spp) di sungai Cikandung dan kolam budidaya Kecamatan Buah Dua Kabupaten Sumedang. Karya Ilmiah. Fakultas Perikanan dan Ilmu Kelautan IPB Bogor.

Susatyo, P., Sugiharto, Lestari, W. 2011. Aspek reproduksi dan ekologis brek (Puntius orphoides) dan lukas (P. bramoides) sebagai dasar domestikasi dan diversifikasi budidaya perikanan. www.scribd.com. [Diakses tanggal 26 Juli 2011].

Sutardja, O. S. 1980. Beberapa aspek biologi ikan lalawak Puntius bramoides (Cuvier \& Valenciennes) di Waduk Jatiluhur Jawa Barat. Karya Ilmiah. Bogor. Fakultas Perikanan IPB.

Yulfiperius. 2006. Domestikasi dan pengembangbiakan dalam upaya pelestarian ikan lalawak (Barbodes sp.). Disertasi: Sekolah Pascasarjana IPB, Bogor. 